\title{
THE USE OF BARK IN BIOMONITORING HEAVY METAL POLLUTION OF FOREST AREAS ON THE EXAMPLE OF SELECTED AREAS IN POLAND
}

\begin{abstract}
In the year 2016, passive biomonitoring studies were conducted in the forest areas of southern and north-eastern Poland: the Karkonosze Mountains (Kark), the Beskidy Mountains (Beskid), Borecka Forest (P. Bor), Knyszynska Forest (P. Kny), and Białowieza Forest (P. Bia). This study used bark from the tree, Betula pendula Roth. Samples were collected in spring ( $\mathrm{Sp}$ ), summer (Su), and autumn (Au). Concentrations of $\mathrm{Mn}, \mathrm{Fe}$, $\mathrm{Ni}, \mathrm{Cu}, \mathrm{Zn}, \mathrm{Cd}$, and $\mathrm{Pb}$ were determined for the samples using the atomic absorption spectrometry method with flame excitation (F-AAS). Based on the obtained results, the studied areas were ranked according to level of heavy-metal deposition: forests of southern Poland > forests of north-eastern Poland. Some seasonal changes in the concentrations of metals accumulated in bark were also indicated, which is directly related to their changing concentrations in the air during the calendar year, for instance, the winter heating season produces higher concentrations of heavy metals in the bark samples taken in spring. When deciding to do biomonitoring studies using bark, but also other biological materials, it is necessary to take into account the period in which the conducted research is done and the time when the samples are taken for analysis, because this will have a significant impact on the obtained results.
\end{abstract}

Keywords: biomonitoring, bark, heavy metals, atomic absorption spectrometry

\section{Introduction}

The increasing rate of pollution in atmospheric aerosol requires the application of an adequate monitoring system. Bioindication methods allow reliable assessments of the environment's condition to be performed in a given area. These methods use, among others, selected species of fauna and flora that accumulate pollution and demonstrate morphological, anatomical, and physiological changes due to its influence [1-4]. The main advantages of methods using biological indicators are, among others, that it is a cheap method of taking samples that does not require special training; and the fact that the accumulation of pollution is the effect of the influence of only those factors that have an impact on the organism's internal balance, at the same time indicating bioaccessibility of the analytes [1, 3-5].

Particular interest has been focused on mosses and lichens due to their good accumulation properties [2,6]. Nevertheless, according to data in the literature [7], the use of trees and bushes as biomonitors is more interesting than mosses and lichens, because

\footnotetext{
${ }^{1}$ Institute of Environmental Engineering and Biotechnology, University of Opole, ul. kard. B. Kominka 6a, 45-032 Opole, Poland, phone +48 774016042 , fax +48 774016051

${ }^{2}$ Department of Physics, University of Hradec Králové, Rokitanského 62, 50003 Hradec Králové, Czech Republic *Corresponding authors: swislowskip@gmail.com, mrajfur@o2.pl
} 
they reflect environmental pollution containing, for example, heavy metals, for a long period of time. Bark and leaves are more frequently used in biomonitoring than other anatomical parts of trees/bushes, such as buds, flowers, or needles; as their structures can accumulate more analytes [8].

Bark and leaves offer a larger surface area for solid particles. It was determined that approximately $148 \mu \mathrm{g} / \mathrm{cm}^{2}$ of particulate matter settled on the leaves of the analysed trees [9].

Bark is dead tissue that always covers the trunks of trees; most pollution is accumulated in the external bark layers, and this is to a depth of approximately $8 \mathrm{~mm} \mathrm{[10].}$ Bark protects the tree from physical damage, water loss, diseases, and pests. Simultaneously, due to its structure, the bark of some tree species offers a good habitat for invertebrates and insects [11].

The advantage of using bark in biomonitoring is the fact that its structure retains pollution for longer and it is widely available without harming the health of the trees. The reason for the effective collection and retention of analytes in tree bark is its structural porosity [12]. Pine bark is particularly useful in studies of atmospheric aerosol pollution levels as it is very porous, and pines grow in large quantities [13]. The pollution that settles on the leaves (in particular on the axial surface) may be rinsed away by rain water or dispersed by wind [14].

Thanks to its large surface area and constant contact with atmospheric aerosol, tree bark is a good bioindicator of the environment in which the tree grows. It is available in diverse areas, but also in urbanised areas where there are no mosses and lichens, and it is easy to collect [13].

The analytes present in atmospheric aerosol are absorbed into the bark's structure and accumulate for years $[15,16]$ due to the settling of wet and dry deposition [17]. Although the mechanisms by which metals accumulate in bark have not been fully studied yet, collecting pollutants from roots can be declared irrelevant [15]. When analysing the increase of trace elements in bark, it is possible to determine, for example, the sources of pollution [18].

The presentation of historical changes in environmental pollution by means of assessing the chemical composition of bark is very complex and has not been sufficiently studied [19].

The bark collected from tree trunks is frequently used as a biomonitor for assessing air pollution levels, despite the fact that the obtained results do not allow for the determination of the changes in analyte concentrations for a given time period [20,21].

Biomonitoring studies use the bark from deciduous trees, among others: oak (Quercus spp.) [10] sweet thorn (Vachellia karroo) [22], walnut (Juglans regia L.) [23], and olive trees (Olea europaea L.) [24], and coniferous, among others: spruce [10] and Scots pine (Pinus sylvestris L.) [25]. Tree bark is used, in addition to other things, as a bioaccumulator in assessing the correlation between heavy metals concentration in bark samples and their deposition in industrial areas [26]. Bark is also used as a long-term bioaccumulator for the air pollution generated by road traffic in urban areas [27]. It is also a good bioindicator of radionuclides [11]. The data in the literature also indicate that bark is a cheap sorbent, frequently used to remove heavy metals from waste water, for example [28, 29].

The results and conclusions from some research are quite controversial due to, among other things, the lack of a standardised methodology for preparing tree bark samples for analyses, and problems with determining material exposure time to pollutants [13, 30]. 
Only a few authors emphasise in their publications that in research using tree bark, the methodology used to take samples of the material is very important [16].

The aim of the study was to compare the heavy metals pollution of forest areas in southern and north-eastern Poland for the heavy metals: $\mathrm{Mn}, \mathrm{Fe}, \mathrm{Ni}, \mathrm{Cu}, \mathrm{Zn}, \mathrm{Cd}$, and $\mathrm{Pb}$, and to identify the potential sources of metals.

\section{Material and methods}

The study used the bark of the tree Betula pendula Roth. Dates of sampling are shown in Table 1.

The dates of biota sampling in 2016

\begin{tabular}{|c|c|c|c|}
\hline Area studied & Spring & Summer & Autumn \\
\hline Karkonosze & $09-11.05$. & $20-22.06$. & $12-14.09$. \\
\hline Beskidy & $25-27.04$. & $27-29.06$. & $05-07.09$. \\
\cline { 1 - 1 } Borecka forest & \multirow{2}{*}{$16-20.05}$. & $04-08.07$. & $19-23.09$. \\
\cline { 1 - 1 } Bnyszynska forest & & & \\
\hline
\end{tabular}

Figure 1 shows the location of the research areas on a map of Poland.

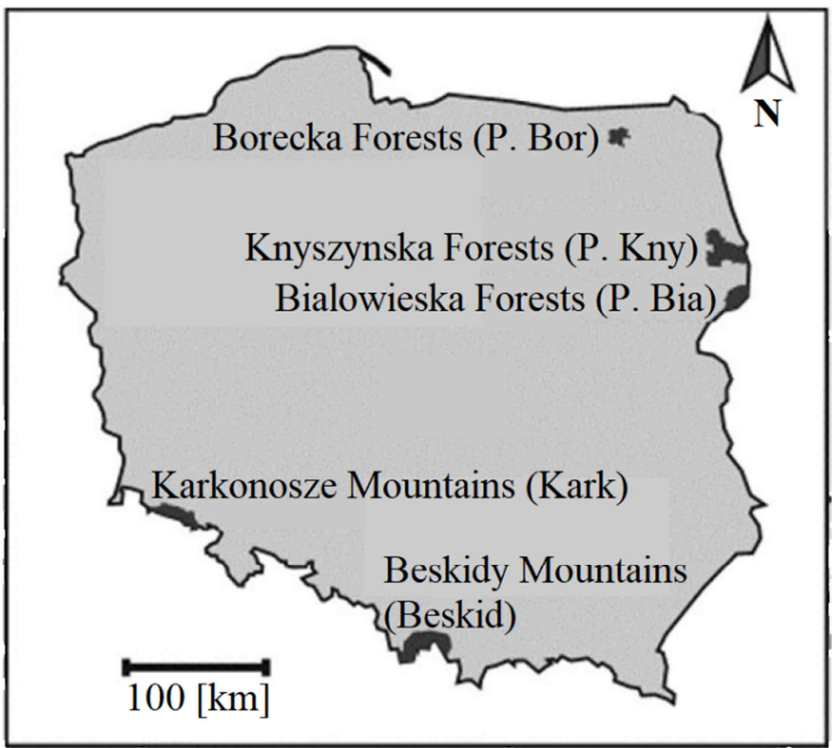

Fig. 1. Location of the sites in Poland where the samples of bark were collected [31]

Samples of bark were collected from trees at a height of $1.5 \mathrm{~m}$ from the ground, and that were located at least $300 \mathrm{~m}$ from busy roads. Samples were taken within a few days. At each site, five subsamples were collected to obtain a sample of bark (five samples per tree). These samples were $1.5 \times 1.5 \mathrm{~cm}$ in size and were taken from the windward side of the tree. From each of the sites (Fig. 1) samples were collected three times. Samples were 
collected in 2016 during one growing season and were collected in spring (Sp), summer $(\mathrm{Su})$ and autumn $(\mathrm{Au})$.

After manually removing impurities and drying the samples at $295 \mathrm{~K}$ to obtain a dry mass (d.m.), the collected material was homogenized and left in closed polyethylene containers. A subsample of $0.4 \mathrm{~g}$ was taken from the homogenized material and mineralised in a mixture of nitric acid(V) and hydrogen dioxide $\left(\mathrm{HNO}_{3} 65 \%: \mathrm{H}_{2} \mathrm{O}_{2} 37 \%=\right.$ proportion $5: 3$ ) in a Speedwave Four microwave oven (BERGHOF, DE). The process temperature was $180{ }^{\circ} \mathrm{C}$. MERCK company reagents were used to prepare the solutions. To determine the heavy metals $(\mathrm{Mn}, \mathrm{Fe}, \mathrm{Ni}, \mathrm{Cu}, \mathrm{Zn}, \mathrm{Cd}$ and $\mathrm{Pb}$ ) concentrations in the bark samples, flame atomic absorption spectroscopy (F-AAS) was used, and the analysis was carried out with an iCE 3500 atomic absorption spectrometer made by Thermo Electron Corporation (USA).

In Table 2, the instrumental detection limits $(I D L)$ and instrumental quantification limits $(I Q L)$ for the iCE 3500 spectrometer are presented. The results were converted into $1 \mathrm{~kg}$ of sample. Calibration of the spectrometer was performed with a standard solution from ANALYTIKA Ltd. (CZ). The values of the highest concentrations of the models used for calibration $\left(2 \mathrm{mg} / \mathrm{dm}^{3}\right.$ for $\mathrm{Cd} ; 5 \mathrm{mg} / \mathrm{dm}^{3}$ for $\mathrm{Ni}, \mathrm{Cu}, \mathrm{Zn}, \mathrm{Pb} ; 7.5 \mathrm{mg} / \mathrm{dm}^{3}$ for $\mathrm{Mn}$; and $10 \mathrm{mg} / \mathrm{dm}^{3}$ for $\mathrm{Fe}$ ) were confirmed as linear limits for signal dependence for concentration.

Table 2

The instrumental detection limits $(I D L)$ and instrumental quantification limits $(I Q L)$ for the iCE 3500 spectrometer $\left[\mathrm{mg} / \mathrm{dm}^{3}\right]$ [32]

\begin{tabular}{|c|c|c|}
\hline Metal & $\boldsymbol{I D L}$ & $\boldsymbol{I Q L}$ \\
\hline $\mathbf{M n}$ & 0.0016 & 0.020 \\
\hline $\mathbf{F e}$ & 0.0043 & 0.050 \\
\hline $\mathbf{N i}$ & 0.0043 & 0.050 \\
\hline $\mathbf{C u}$ & 0.0045 & 0.033 \\
\hline $\mathbf{Z n}$ & 0.0033 & 0.010 \\
\hline $\mathbf{C d}$ & 0.0028 & 0.013 \\
\hline $\mathbf{P b}$ & 0.0130 & 0.070 \\
\hline
\end{tabular}

The concentrations of heavy metals in the certified reference materials, BCR-482 lichen, produced at the Institute for Reference Materials and Measurements, Belgium, are shown in Table 3.

Table 3

Comparison of the measured and certified concentrations in BCR-482 lichen

\begin{tabular}{|c|c|c|c|c|c|}
\hline \multirow{3}{*}{ Metal } & \multicolumn{2}{|c|}{ BCR-482 lichen } & \multicolumn{2}{|c|}{$\mathbf{A A S}$} & \multirow{2}{*}{ Dev.** } \\
\hline & Concentration & Uncertainty & Average & $\pm S D^{*}$ & \\
\hline & \multicolumn{4}{|c|}{$[\mathrm{mg} / \mathrm{kg}$ d.m.] } & {$[\%]$} \\
\hline Mn & 33.0 & 0.50 & 31.70 & 0.68 & -3.90 \\
\hline $\mathbf{F e}$ & 804 & 160 & n.d. & n.d. & n.d. \\
\hline $\mathbf{N i}$ & 2.47 & 0.07 & 2.16 & 0.32 & -13 \\
\hline $\mathbf{C u}$ & 7.03 & 0.19 & 6.63 & 0.17 & -5.70 \\
\hline Zn & 101 & 2.20 & 95.1 & 2.30 & -5.50 \\
\hline Cd & 0.56 & 0.02 & 0.53 & 0.03 & -5.30 \\
\hline $\mathbf{P b}$ & 40.9 & 1.40 & 38.2 & 1.00 & -6.60 \\
\hline
\end{tabular}

* - standard deviation, ${ }^{* *}$ - relative difference between the measured $\left(c_{\mathrm{z}}\right)$ and certified $\left(c_{\mathrm{c}}\right)$ concentration $100 \% \cdot\left(c_{\mathrm{z}}-c_{\mathrm{c}}\right) / c_{\mathrm{c}}$, n.d. - not determined 
The description of the statistical parameters for the distribution of heavy metals concentrations that had accumulated in the bark samples has been visualised in the form of box plots. In order to assess the relative differentiation for the distribution of the results of analytes concentration levels in the bark collected from the studied area, the coefficient of variation, $C V$, was determined, which refers the value of standard deviation, $S D$, (absolute differentiation of the feature distribution) to the mean value of $x$ [33]:

$$
C V=\frac{S D}{x} \cdot 100 \%
$$

\section{Results and discussion}

The results of the research were interpreted by comparing the concentrations of the determined heavy metals accumulated in the bark samples.

Figure 2 presents the concentrations of the selected metals that had accumulated in the tree bark samples collected in 2016 from the designated areas. The results presented in the Figure 2 show that in considering the pollution levels of $\mathrm{Mn}, \mathrm{Ni}, \mathrm{Cu}, \mathrm{Cd}$, and $\mathrm{Pb}$, the studied areas can be ranked as follows: southern areas of the country > north-east Poland. Analysing the study results in relation to the pollution levels of these analytes for all areas, and determining mean values for those areas, it was determined that the concentrations of the analysed elements in the studied areas can be ranked as follows: $\mathrm{Mn}>\mathrm{Fe}>\mathrm{Zn}>\mathrm{Pb}>$ $\mathrm{Cd}>\mathrm{Cu}>\mathrm{Ni}$.

a)

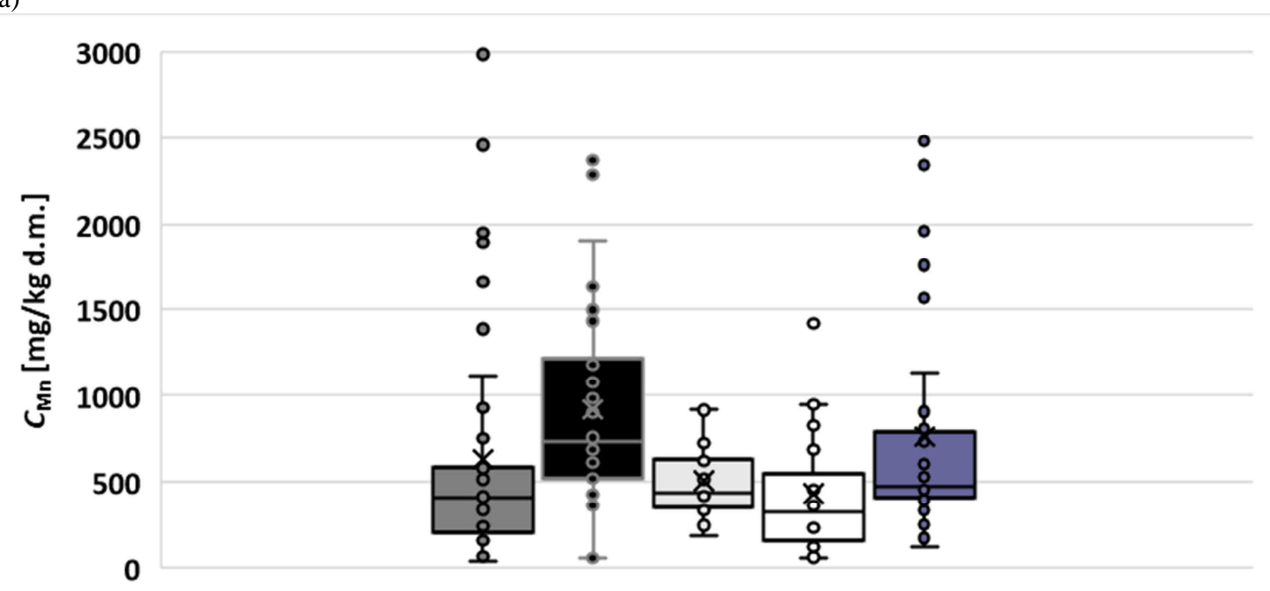

Kark $\square$ Beskid $\square$ P. Bia $\square$ P. Bor $\square$ P. Kny 
b)

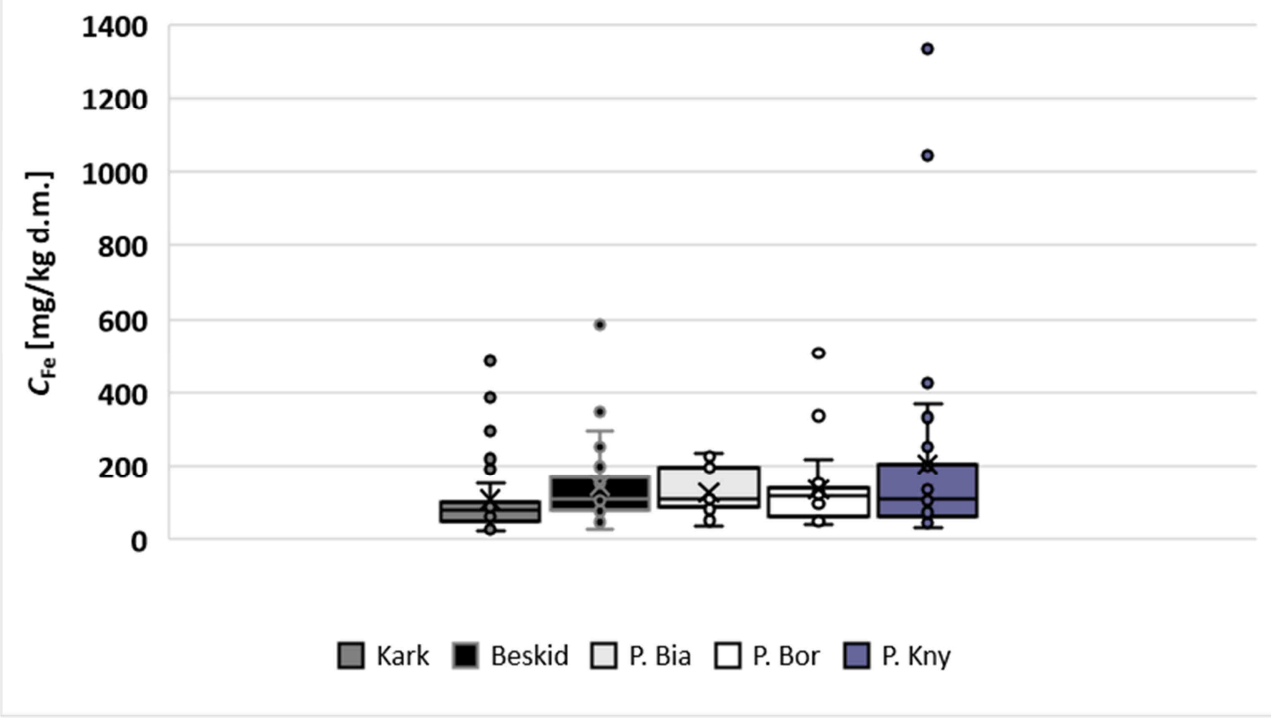

c)

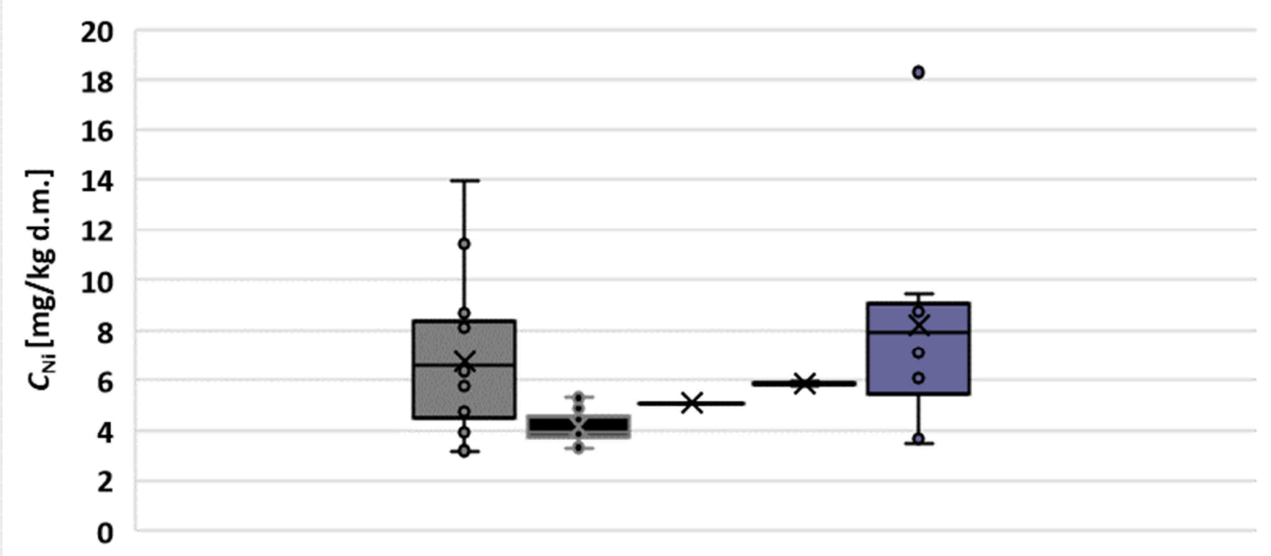

$\square$ Kark $\square$ Beskid $\square$ P. Bia $\square$ P. Bor $\square$ P. Kny 
d)

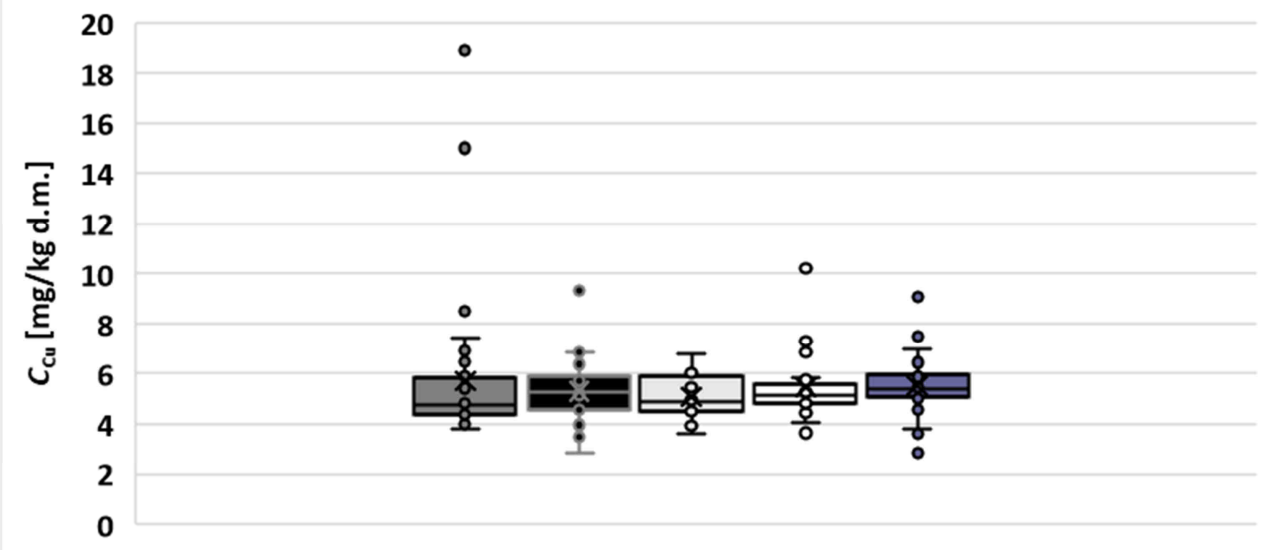

Kark $\square$ Beskid $\square$ P. Bia $\square$ P. Bor $\square$ P. Kny

e)

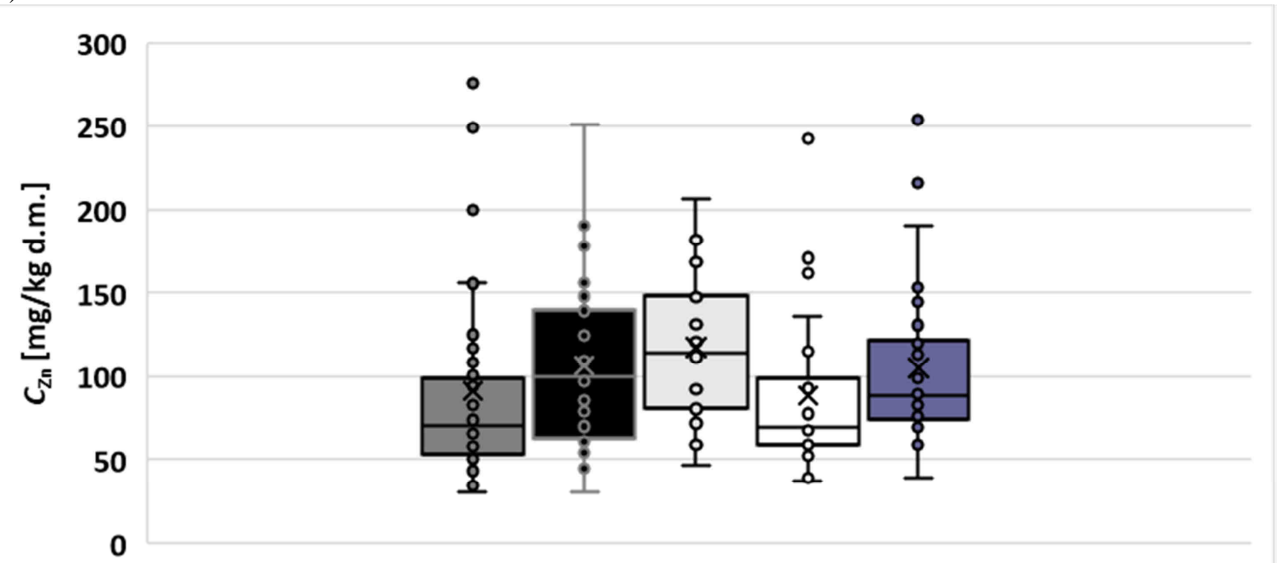

Kark $\square$ Beskid $\square$ P. Bia $\square$ P. Bor $\square$ P. Kny 
f)

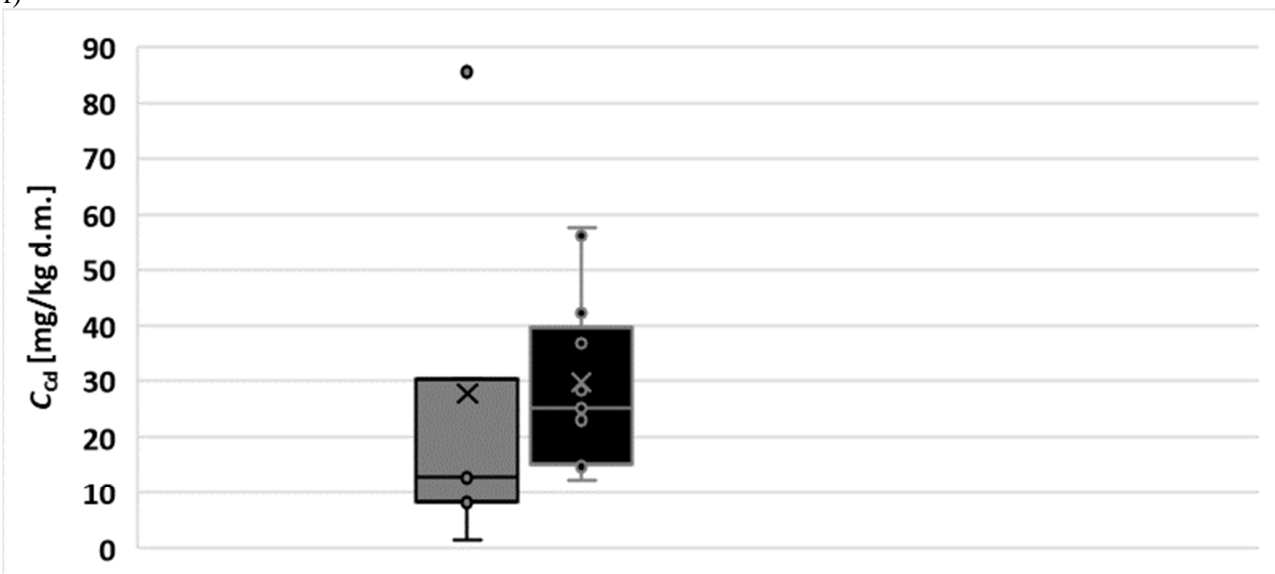

Kark Beskid $\square$ P. Bia $\square$ P. Bor $\square$ P. Kny

g)

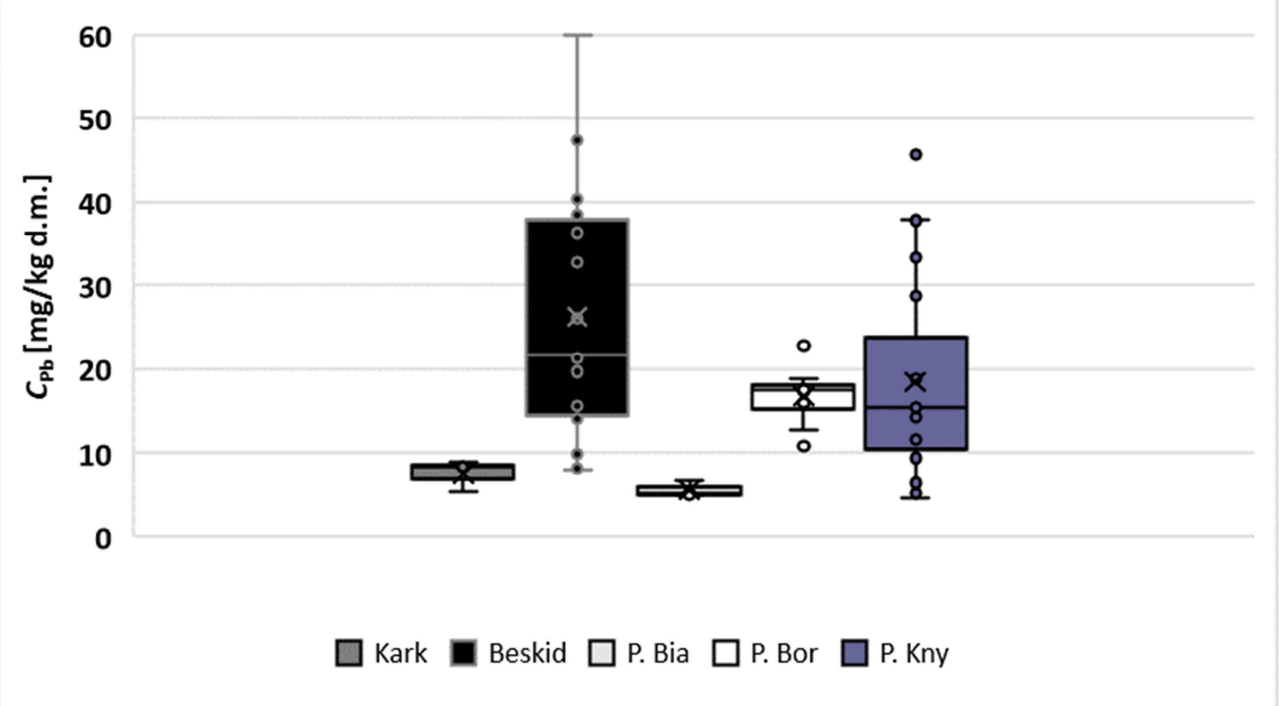

Fig. 2. Concentrations of the determined heavy metals that had accumulated in bark samples: a) manganese, b) iron, c) nickel, d) copper, e) zinc, f) cadmium, g) lead

The results indicate considerable $\mathrm{Cd}$ and $\mathrm{Pb}$ pollution levels in the south. Cadmium and lead were determined in those bark samples collected in southern Poland - the Karkonosze and Beskid Mountains - however, mean concentration values were higher in the samples from Beskid Mountains. In the north-east of the country, the concentration of these elements was below the detection limit of the applied analytical method (Table 4). 
The box charts in Figure 3 show the seasonal changes in $\mathrm{Mn}, \mathrm{Fe}, \mathrm{Ni}, \mathrm{Cu}, \mathrm{Zn}, \mathrm{Cd}$ and $\mathrm{Pb}$, concentrations in the samples of bark.

a)

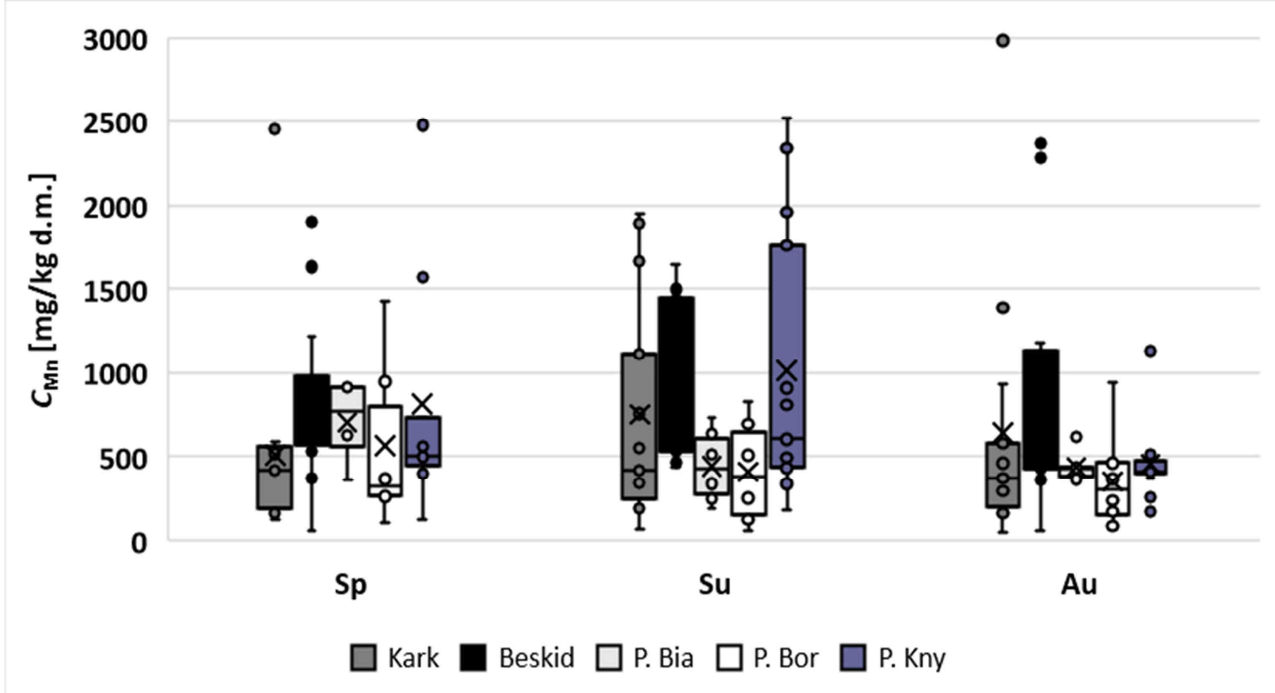

b)

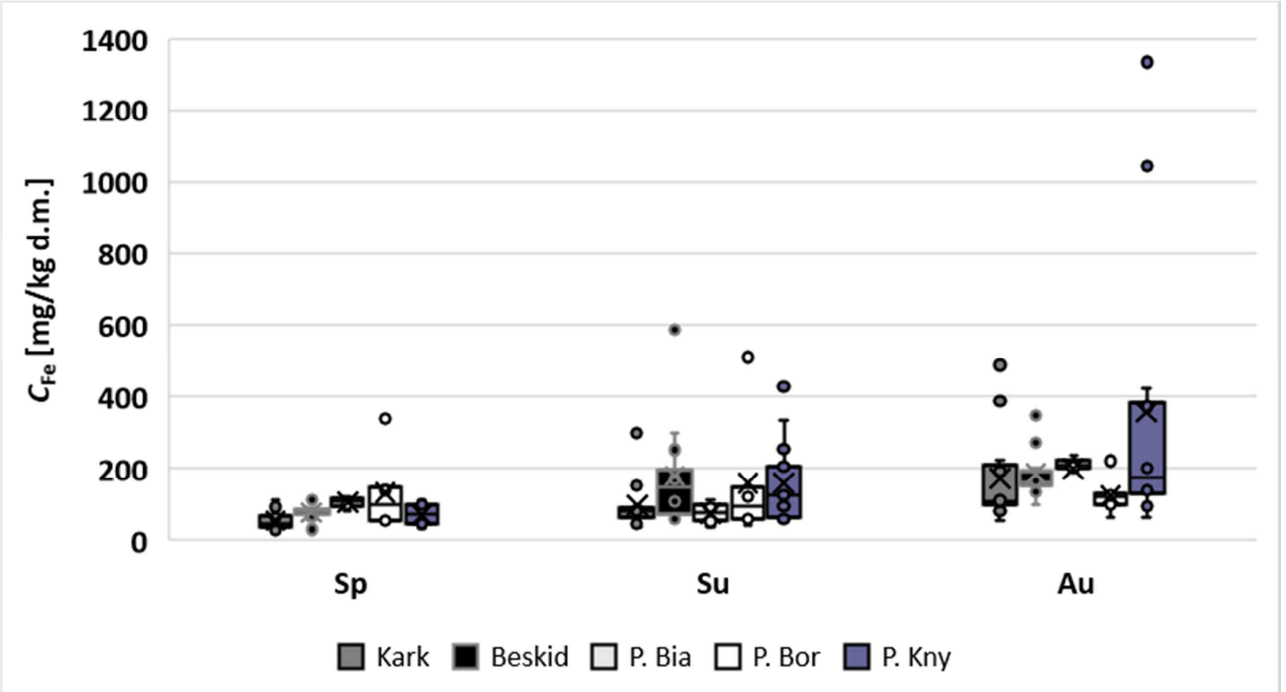


c)

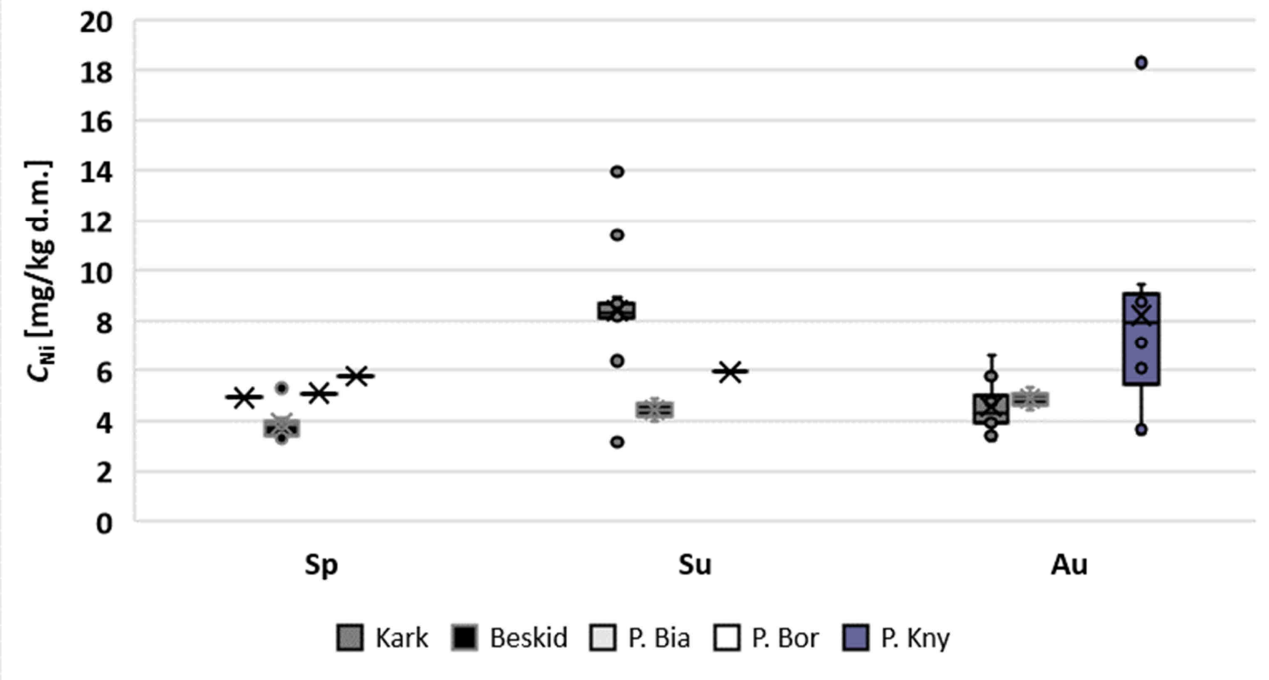

d)

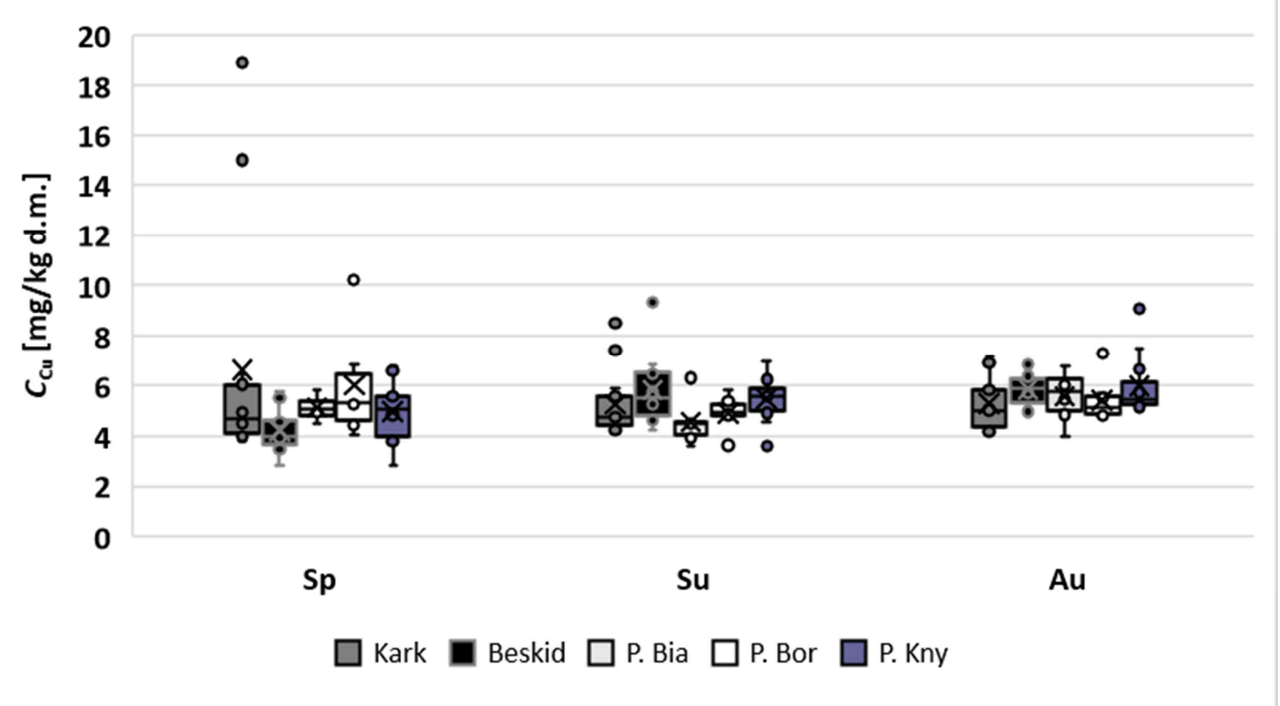


e)

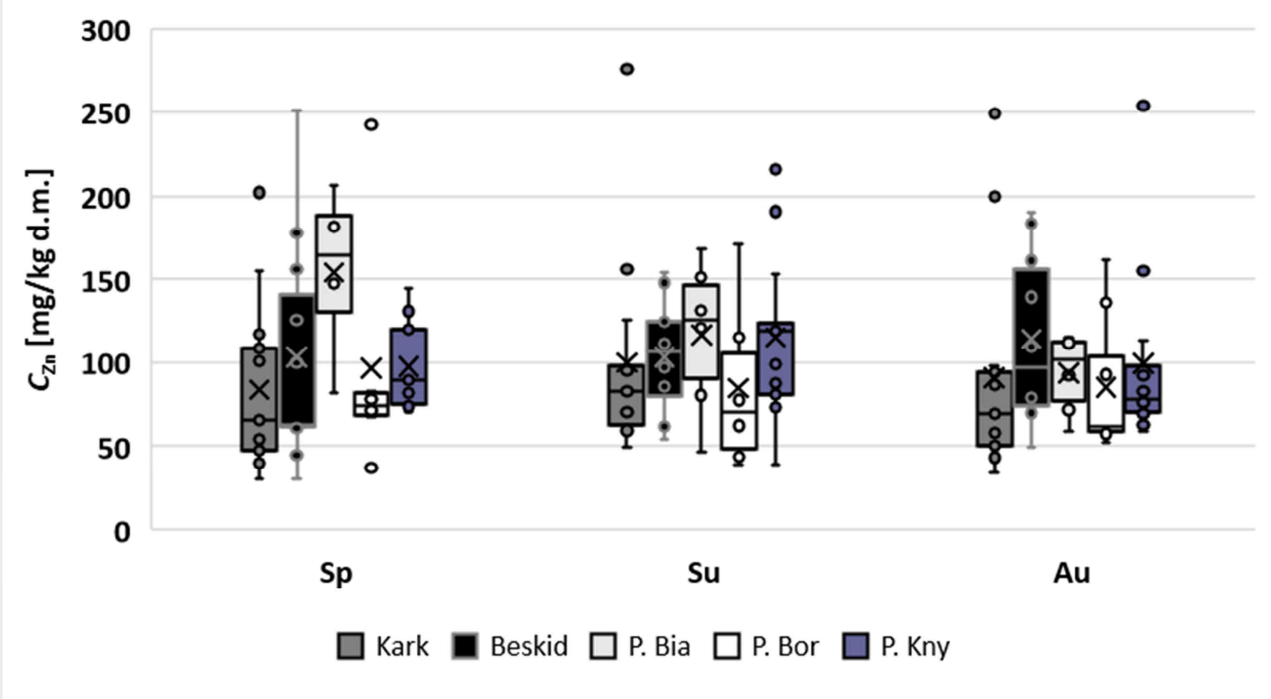

f)

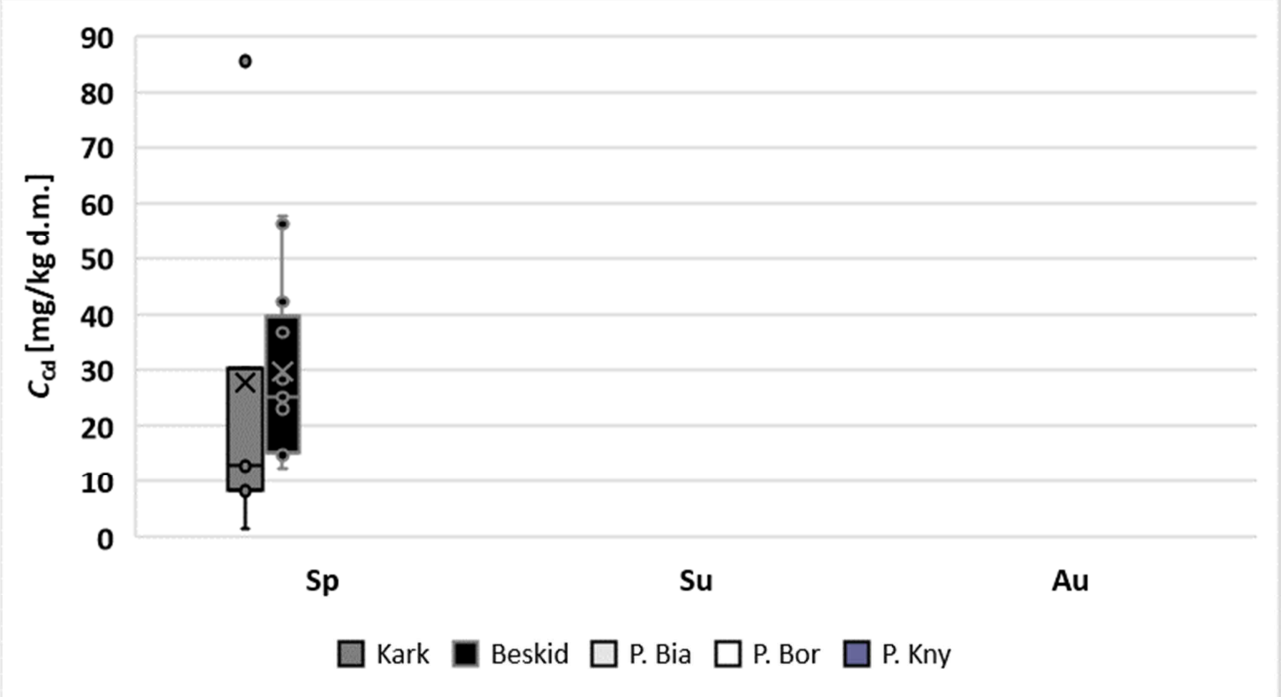


g)

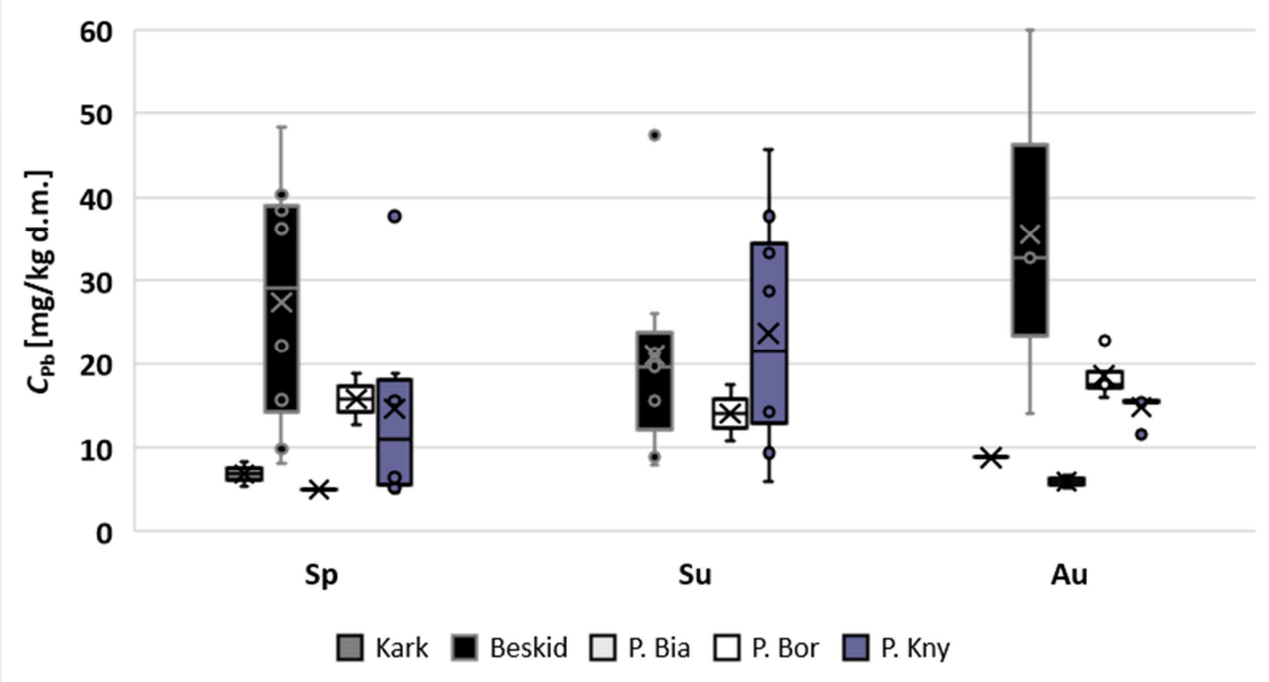

Fig. 3. Seasonal changes in the concentration of heavy metals in bark samples ( $\mathrm{Sp}$ - spring, $\mathrm{Su}$ - summer, Au - autumn): a) manganese, b) iron, c) nickel, d) copper, e) zinc, f) cadmium, g) lead

Manganese concentrations in the samples differed considerably across the vegetation season. The highest concentrations were determined during autumn in the south of Poland. In Knyszynska Forest, large Mn concentrations were also determined in the samples collected in summer, while high Fe concentrations were determined in the samples collected during autumn. There were no statistically significant differences in $\mathrm{Fe}$ concentrations in the samples collected from the studied areas during spring and summer. In the case of nickel, which was determined only in some samples, the highest amount was recorded in the samples collected in autumn in Knyszynska Forest and in summer in the Karkonosze Mountains. Copper concentrations were on a comparable levels in all studied areas throughout the whole vegetation season. The highest zinc concentrations were determined in samples collected in spring in southern areas, and Białowieza Forest. Cadmium was determined only in samples of bark collected in spring in the south of Poland, which may be caused by the 'low emissions' of pollution during the warming season. The highest $\mathrm{Pb}$ concentrations were determined in samples collected in autumn from the Beskid Mountains' area.

In comparing the results of the presented studies with the results presented in the publication of [31], it can be declared that bark is not as sensitive a biomonitor as mosses and lichens. For example, cadmium was measured only in bark samples collected in spring in the Karkonosze and Beskid Mountains; whereas this metal was determined in moss and lichen samples collected during the whole study season, with its highest concentration also detected in the samples collected in spring in the Karkonosze and Beskid Mountains.

The results of our own study on the distribution of heavy metals concentrations in bark samples were compared to the mean values of concentrations of the analytes that had accumulated in mosses and lichen samples collected in 2016 from the same areas, within the project: Ecosystem Stress from the Combined Effects of Winter Climate 
Change and Air Pollution - How do the Impacts Differ between Biomes, WICLAP, POL-NOR/198571/83/2013, and are presented in Table 4 [31].

Comparison of the mean values of concentrations of heavy metals determined in bark samples, with the mean values of concentrations of these analytes determined in moss and lichen samples [mg/kg d.m.]

\begin{tabular}{|c|c|c|c|c|c|c|}
\hline \multirow{2}{*}{ Metal } & Mosses & Lichens & Bark & Mosses & Lichens & Bark \\
\cline { 2 - 7 } & \multicolumn{3}{|c|}{ S Poland } & \multicolumn{3}{|c|}{ N-E Poland } \\
\hline $\mathbf{N i}$ & 3.00 & 2.33 & 2.75 & $<1.50$ & $<1.32$ & 0.970 \\
\hline $\mathbf{Z n}$ & 48.3 & 85.2 & 99.2 & 33.8 & 62.6 & 105 \\
\hline $\mathbf{C d}$ & 10.1 & 25.0 & 6.72 & $<0.320$ & $<0.570$ & - \\
\hline Pb & 9.98 & 13.7 & 7.43 & 13.0 & 14.4 & 5.89 \\
\hline
\end{tabular}

"-" impossible to determine mean value

Higher concentration levels of the analysed elements were determined in the moss and lichen samples collected in the south in comparison to the samples collected in north-eastern areas (except for $\mathrm{Pb}$ ). Higher concentration of $\mathrm{Zn}$ and lower concentrations of other elements were determined in the bark samples collected at the same measurement points. Based on the data from Table 4 it should be stated that mosses and lichens are very good sorbents of heavy metals.

The areas of southern Poland were more polluted with the determined heavy metals than the compared forest areas in the north-east of the country. This fact is also indicated by studies of the assessment of heavy metals pollution in Beskid Zywiecki and other areas in the south [34, 35]. The mean concentration of heavy metals in lichens (Hypogymnia physodes) collected in Beskid Zywiecki in 2012 was: Ni - $1.20 \mathrm{mg} / \mathrm{kg}$; Zn - $189 \mathrm{mg} / \mathrm{kg}$; $\mathrm{Cd}-3.83 \mathrm{mg} / \mathrm{kg}$; and for $\mathrm{Pb}-67.7 \mathrm{mg} / \mathrm{kg}$ [34]. In 2014, in samples of lichens (Hypogymnia physodes) collected in the vicinity of the former zinc and lead works near Olkusz (southern Poland), the following concentrations of heavy metals were determined: $\mathrm{Zn}-471 \mathrm{mg} / \mathrm{kg}$; $\mathrm{Cd}-3.16 \mathrm{mg} / \mathrm{kg}$; and $\mathrm{Pb}-51.5 \mathrm{mg} / \mathrm{kg}$ [35].

Table 5

Comparison of the value of coefficient of variation, $C V$ [\%], for the samples of bark, mosses, and lichens collected in the same forest areas in Poland

\begin{tabular}{|c|c|c|c|c|c|c|c|c|c|c|c|c|c|c|c|c|}
\hline & \multicolumn{3}{|c|}{ Kark } & \multicolumn{3}{|c|}{ Beskid } & \multicolumn{3}{|c|}{ P. Bia } & \multicolumn{3}{|c|}{ P. Bor } & \multicolumn{3}{|c|}{ P. Kny } \\
\hline & & $\mathbf{M}$ & $\mathbf{L}$ & B & M & $\mathbf{L}$ & B & $\mathbf{M}$ & $\mathbf{L}$ & B & M & $\mathbf{L}$ & B & $\mathbf{M}$ & $\mathbf{L}$ & B \\
\hline \multirow{3}{*}{$\mathbf{N i}$} & Sp & 144 & 57.1 & - & 10.0 & 6.25 & 16.5 & - & - & - & - & - & - & - & - & - \\
\hline & $\mathrm{Su}$ & - & - & 29.8 & - & - & 14.3 & - & - & - & - & - & - & - & - & - \\
\hline & Au & - & - & 23.9 & - & - & 12.7 & - & - & - & - & - & - & - & - & 56.7 \\
\hline \multirow{3}{*}{ Zn } & Sp & 25.6 & 29.7 & 60.8 & 27.0 & 20.9 & 66.0 & 43.2 & 27.9 & 35.2 & 17.2 & 32.8 & 75.9 & 31.0 & 33.3 & 28.0 \\
\hline & Su & 34.8 & 22.8 & 60.5 & 36.5 & 36.6 & 31.6 & 29.3 & 35.2 & 38.9 & 36.3 & 50.7 & 59.3 & 34.8 & 22.8 & 42.6 \\
\hline & Au & 37.1 & 30.8 & 69.9 & 47.7 & 21.6 & 44.9 & 44.1 & 39.3 & 25.3 & 46.3 & 23.4 & 48.8 & 24.9 & 20.0 & 55.7 \\
\hline \multirow{3}{*}{ Cd } & Sp & 57.9 & 34.2 & 123 & 33.0 & 87.8 & 55.5 & - & - & - & - & - & - & - & - & - \\
\hline & $\mathrm{Su}$ & - & - & - & 44.4 & 46.7 & - & - & - & - & - & - & - & - & - & - \\
\hline & Au & - & - & - & - & - & - & - & - & - & - & - & - & - & - & - \\
\hline \multirow{3}{*}{$\mathbf{P b}$} & Sp & - & 53.1 & 30.4 & 45.6 & 38.5 & 55.9 & 43.2 & 32.4 & - & 75.7 & 80.3 & 27.5 & 90.9 & 116 & 86.8 \\
\hline & $\mathrm{Su}$ & 88.5 & 27.7 & - & 41.3 & 45.1 & 63.6 & 33.3 & 23.1 & - & - & - & 33.2 & 88.5 & 27.7 & 61.7 \\
\hline & $\mathbf{A u}$ & 32.7 & 21.6 & - & 54.1 & 31.6 & 64.8 & 31.5 & 12.4 & 19.4 & 99.0 & 99.1 & 16.2 & 26.8 & 27.6 & 12.2 \\
\hline
\end{tabular}

“-” impossible to determine $C V$ coefficient 
The analysis of mean values of heavy metals concentration levels determined in moss, lichen, and birch bark samples identified correlations between concentrations of the analytes in bark and other biomonitors, which proves that it is suitable for the analysis of the spatial distribution of concentrations in selected study areas. At the same time it was determined that deciduous tree bark may serve as a biological indicator of atmospheric aerosol heavy metals pollution.

Table 5 presents the calculated $C V$ values for the bark samples collected from the study areas, with the $C V$ values determined from moss and lichen samples collected from the same measurement points.

The analysis of the data presented in Table 5 allows us to conclude that bark, in comparison to other biomonitors, shows the largest differentiation in the distribution of results. The values of the $C V$ coefficient determined for the samples of bark collected across different seasons in the studied areas, indicate it contains pollution from a heterogeneous range of heavy metals. The effect is particularly significant for the data for zinc (results in bold). Despite the fact that bark, in comparison to mosses and lichens, is less homogeneous, it can be successfully used as a bioindicator of seasonal changes of heavy metals concentration levels in atmospheric aerosol.

\section{Conclusion}

The results of the research prove that biomonitoring with the use of deciduous tree bark is a good complement to the classic methods of assessing the quality of the environment in terms of contamination with heavy metals. It makes it to assess the level of pollution of the studied areas, identify sources of pollution origin. Seasonal changes in concentrations of metals accumulated in bark were observed. An example of this is the seasonal variations in cadmium concentrations which can result from low emissions during the heating season.

There is a correlation between the concentration levels of analytes in tree bark and other biomonitors, which proves its usefulness in the analyses of the spatial distribution of concentrations in the selected study areas.

The research findings presented above show that southern Poland is more polluted with heavy materials compared to northern Poland. The information contained in the articles of other authors was also confirmed as being considerably increased, which emphasises the reliability of the obtained data.

\section{References}

[1] Kłos A. Porosty w biomonitoringu środowiska (Lichens in environmental biomonitoring). Opole: University of Opole; 2009. ISBN: 9788373952607.

[2] Kłos A, Rajfur M, Šramek I, Wacławek M. Mercury concentration in lichen, moss and soil samples collected from the forest areas of Praded and Glacensis Euroregions (Poland and Czech Republic). Environ Monit Assess. 2012;184:6765-74. DOI: 10.1007/s10661-011-2456-1.

[3] Świsłowski P, Rajur M. Mushrooms as biomonitors of heavy metals contamination in forest areas. Ecol Chem Eng S. 2018;25(4):557-68. DOI: 10.1515/eces-2018-0037.

[4] Aleksiayenak Y, Frontasyeva M. A ten-year biomonitoring study of atmospheric deposition of trace elements at the territory of the Republic of Belarus. Ecol Chem Eng S. 2019;26(3):455-64. DOI: 10.1515/eces-2019-0034.

[5] Ramachandra TV, Sudarshan PB, Mahesh MK, Vinay S. Spatial patterns of heavy metal accumulation in sediments and macrophytes of Bellandur wetland, Bangalore. J Environ Manage. 2018;206:1204-10. DOI: 10.1016/j.jenvman.2017.10.014. 
[6] Meyer C, Diaz-de-Quijano M, Monna F, Franchi M, Toussaint ML, Gilbert D, et al. Characterisation and distribution of deposited trace elements transported over long and intermediate distances in north-eastern France using Sphagnum peatlands as a sentinel ecosystem. Atmos Environ. 2015;101:286-93. DOI: 10.1016/j.atmosenv.2014.11.041.

[7] Allahabadi A, Ehrampoush MH, Miri M, Aval HE, Yousefzadeh S, Ghaffari HR, et al. A comparative study on capability of different tree species in accumulating heavy metals from soil and ambient air. Chemosphere. 2017;172:459-67. DOI: 10.1016/j.chemosphere.2017.01.045.

[8] Matin G, Kargar N, Buyukisik HB. Bio-monitoring of cadmium, lead, arsenic and mercury in industrial districts of Izmir, Turkey by using honey bees, propolis and pine tree leaves. Ecol Eng. 2016;90:331-5. DOI: 10.1016/j.ecoleng.2016.01.035.

[9] Song Y, Maher BA, Li F, Wang X, Sun X, Zhang H. Particulate matter deposited on leaf of five evergreen species in Beijing, China: source identification and size distribution. Atmos Environ. 2015;105:53-60. DOI: 10.1016/j.atmosenv.2015.01.032.

[10] Cosma C, Iurian AR, Incze R, Kovacs T, Žunić ZS. The use of tree bark as long term biomonitor of ${ }^{137} \mathrm{Cs}$ deposition. J Environ Radioactiv. 2016;153:126-33. DOI: 10.1016/j.jenvrad.2015.12.019

[11] Belivermiş M, Kılıç Ö, Çotuk Y, Topcuoğlu S, Kalaycı G, Peştreli D. The usability of tree barks as long term biomonitors of atmospheric radionuclide deposition. App Radia Isotopes. 2010;68:2433-7. DOI: 10.1016/j.apradiso.2010.07.010.

[12] Berlizov AN, Blum OB, Filby RH, Malyuk IA, Tryshyn VV. Testing applicability of black poplar (Populus nigra L.) bark to heavy metal air pollution monitoring in urban and industrial regions. Sci Total Environ. 2007;372:693-706. DOI: 10.1016/j.scitotenv.2006.10.029.

[13] Forbes PBC, van der Wat L, Kroukamp EM. Chapter 3 - Biomonitors. In: Monitoring of Air Pollutants: Sampling, Sample Preparation and Analytical Techniques. Comprehensive Anal Chem. 2015;70:53-108. DOI: 10.1016/bs.coac.2015.09.003.

[14] Sawidis T, Breuste J, Mitrovic M, Pavlovic P, Tsigaridas K. Trees as bioindicator of heavy metal pollution in three European cities. Environ Pollut. 2011;159:3560-70. DOI: 10.1016/j.envpol.2011.08.008.

[15] Catinon M, Ayrault S, Spadini L, Boudouma O, Asta J, Tissut M, et al. Tree bark suber-included particles: a long-term accumulation site for elements of atmospheric origin. Atmos Environ. 2011;45:1102-9. DOI: 10.1016/j.atmosenv.2010.11.038.

[16] Chiarantini L, Rimondi V, Benvenuti M, Beutel MW, Costagliola P, Gonnelli C, et al. Black pine (Pinus nigra) barks as biomonitors of airborne mercury pollution. Sci Total Environ. 2016;569-570:105-13. DOI: 10.1016/j.scitotenv.2016.06.029.

[17] Minganti V, Drava G, Giordani P, Malaspina P, Modenesi P. Human contribution to trace elements in urban areas as measured in holm oak (Quercus ilex L.) bark. Environ Sci Pollut Res Int. 2016;23:12467-73. DOI: 10.1007/s11356-016-6485-8.

[18] Khokhotva O, Waara S. The influence of dissolved organic carbon on sorption of heavy metals on urea-treated pine bark. J Hazard Mater. 2010;173:689-96. DOI: 10.1016/j.jhazmat.2009.08.149.

[19] Cocozza C, Ravera S, Cherubini P, Lombardi F, Marchetti M, Tognetti R. Integrated biomonitoring of airborne pollutants over space and time using tree rings, bark, leaves and epiphytic lichens. Urban Forestry Urban Green. 2016;17:177-91. DOI: 10.1016/j.ufug.2016.04.008.

[20] Drava G, Brignole D, Giordani P, Minganti V. Urban and industrial contribution to trace elements in the atmosphere as measured in holm oak bark. Atmos Environ. 2016;144:370-5. DOI: 10.1016/j.atmosenv.2016.09.009.

[21] Drava G, Anselmo M, Brignole D, Giordani P, Minganti V. Branch bark of holm oak (Quercus ilex L.) for reconstructing the temporal variations of atmospheric deposition of hexavalent chromium. Chemosphere. 2017;170:141-5. DOI: 10.1016/j.chemosphere.2016.12.012.

[22] Sedumedi HN, Mandiwana KL, Ngobeni P, Panichev N. Speciation of Cr(VI) in environmental samples in the vicinity of the ferrochrome smelter. J Hazard Mater. 2009;172:1686-9. DOI: 10.1016/j.jhazmat.2009.07.111.

[23] Dogan Y, Unver MC, Ugulu I, Calis M, Durkan N. Heavy metal accumulation in the bark and leaves of Juglans regia planted in Artvin City, Turkey. Biotechnol Biotechnol Equip. 2014;28:643-9. DOI: 10.1080/13102818.2014.947076.

[24] Pacheco AMG, Freitas MC, Barros LIC, Figueira R. Investigating tree bark as an air-pollution biomonitor by means of neutron activation analysis. $J$ Radioanal Nucl Chem. 2001;249:327-31. DOI: 10.1023/A:1013293814789.

[25] Birke M, Rauch U, Hofmann F. Tree bark as a bioindicator of air pollution in the city of Stassfurt, Saxony-Anhalt, Germany. J Geochem Explor. 2018;187:97-117. DOI: 10.1016/j.gexplo.2017.09.007. 
[26] Pacheco AMG, Freitas MC, Baptista MS, Vasconcelos MTSD, Cabral IJP. Elemental levels in tree-bark and epiphytic-lichen transplants at a mixed environment in mainland Portugal, and comparisons with in situ lichen. Environ Pollut. 2008;151:326-33. DOI: 10.1016/j.envpol.2007.06.038.

[27] Moreira TCL, de Oliveira RC, Lourenço Amato LF, Kang CM, Nascimento Saldiva PH, Saiki M. Intraurban biomonitoring: Source apportionment using tree barks to identify air pollution sources. Environ Int. 2016;91:271-5. DOI: 10.1016/j.envint.2016.03.005.

[28] Nehrenheim E., Gustafsson JP. Kinetic sorption modelling of $\mathrm{Cu}, \mathrm{Ni}, \mathrm{Zn}, \mathrm{Pb}$ and $\mathrm{Cr}$ ions to pine bark and blast furnace slag by using batch experiments. Bioresour Technol. 2008;99:1571-7. DOI: 10.1016/j.biortech.2007.04.017.

[29] Ribé V, Nehrenheim E, Odlare M, Gustavsson L, Berglind R, Forsberg Å. Ecotoxicological assessment and evaluation of a pine bark biosorbent treatment of five landfill leachates. Waste Manage. 2012;32:1886-94. DOI: 10.1016/j.wasman.2012.05.011.

[30] Marć M, Tobiszewski M, Zabiegała B, Guardia MDL, Namieśnik J. Current air quality analytics and monitoring: A review. Anal Chim Acta. 2015;853:116-26. DOI: 10.1016/j.aca.2014.10.018.

[31] Kłos A, Ziembik Z, Rajfur M, Dołhańczuk-Śródka A, Bochenek Z, Bjerke JW, et al. Using moss and lichens in biomonitoring of heavy-metal contamination of forest areas in southern and north-eastern Poland. Sci Total Environ. 2018;627:438-49. DOI: 10.1016/j.scitotenv.2018.01.211.

[32] iCE 3000 Series AA Spectrometers Operators Manuals. Cambridge: Thermo Fisher Scientific; 2011. http://photos.labwrench.com/equipmentManuals/9291-6306.pdf.

[33] Konieczka P, Namieśnik J. Quality Assurance and Quality Control in the Analytical Chemical Laboratory. A Practical Approach. Second edition. London: CRC Press/Balkema; 2018. ISBN: 9781138196728

[34] Klimek B, Tarasek A, Hajduk J. Trace element concentrations in lichens collected in the Beskidy Mountains, the Outer Western Carpathians. Bull Environ Contam Toxicol. 2015;94:532-6. DOI: 10.1007/s00128-015-1478-8.

[35] Zakrzewska M, Klimek B. Trace element concentrations in tree leaves and lichen collected along a metal pollution gradient near Olkusz (Southern Poland). Bull Environ Contam Toxicol. 2018;100:245-9. DOI: 10.1007/s00128-017-2219-y. 